\begin{tabular}{l}
\hline \\
1. MBBS \\
Resident \\
Department of Gastroenterology \\
Liaquat National Hospital Karachi. \\
2. FCPS \\
Assistant Professor \\
Department of Gastroenterology \\
LUMHS Jamshoro. \\
3. FCPS \\
Assistant Professor \\
Department of Radiology \\
LUMHS Jamshoro. \\
4. MBBS \\
Resident \\
Department of Urology \\
Sheikh Zayed Hospital Lahore. \\
5. MBBS \\
Resident \\
Department of Cardiology \\
Shaikh Zaid Hospital Lahore. \\
Correspondence Address: \\
Dr. Riaz Hussain Awan \\
Flat No. 204 Muhammadi Tower \\
Naseem Nagar Qasimabad \\
Hyderabad. \\
zulfikar229@hotmail.com \\
Article received on: \\
29/03/2018 \\
Accepted for publication: \\
19/09/2018 \\
Received after proof reading: \\
31/07/2019 \\
\end{tabular}
31/07/2019

\section{FREQUENCY OF HELICOBACTER PYLORI IN PATIENTS WITH FUNCTIONAL DYSPEPSIA.}

\begin{abstract}
Tooba1, Riaz Hussain Awan², Seema Nayab³, Khadim Hussain Awan', Faqir Muhammad Awan ${ }^{5}$
ABSTRACT... To evaluate the frequency of Helicobacter pylori in individuals with functional dyspepsia. Study Design: Cross sectional descriptive study. Period: Six months from 01-May2014 to 31-10-2014. Setting: Liaquat National Hospital, Karachi. Materials and Methods: All the patients between 18 to 70 years of age diagnosed as functional dyspepsia for more than 03 months duration were admitted and evaluated for Helicobacter pylori infection through histopathological examination. Results: Total 121 subjects with functional dyspepsia were screened for Helicobacter pylori infection. The mean \pm SD for age of subjects with functional dyspepsia was $41.74 \pm 08.87$. The mean age $\pm S D$ of Helicobacter pylori infected individuals was $40.70 \pm 7.82$ while the mean \pm SD of age in helicobacter pylori negative patients was $40.55 \pm 10.63$. Majority of the subjects were out-patients, 30-39 years of age with male predominance. The most common duration of disease observed was 6-9 months with epigastric pain and burning the predominant symptoms. The Helicobacter pylori infection was observed in $78(64.4 \%)$ individuals, of which 55 were males and 23 were males $(p=<0.01)$. Conclusion: The functional dyspeptic patients are prone to acquire Helicobacter pylori infection therefore present study reported $64.4 \%$ prevalence for $\mathrm{H}$. pylori infection with male gender predominance.
\end{abstract}

Key words: $\quad$ Dyspepsia, Functional Dyspepsia, Helicobacter Pylori Infection, Peptic ulcer

Article Citation: Tooba, Awan RH, Nayab S, Awan KH, Awan FM. Frequency of helicobacter pylori in patients with functional dyspepsia. Professional Med J 2019; 26(8):1261-1265. DOI: 10.29309/TPMJ/2019.26.08.3866

\section{INTRODUCTION}

Dyspepsia or indigestion is a umbrella term occupies the wide range of conditions and the diagnose depends on patients clinical history, physical examination and laboratory investigations. ${ }^{2-4}$ In dyspeptic individuals the peptic ulcer remit and relapse and during endoscopy the ulcer can be absent along with the existence of Helicobacter pylori infection and the conditions termed as non ulcer dyspepsia. ${ }^{5}$ Dyspepsia can be categorized in functional dyspepsia (FD) and organic dyspepsia depending on the symptomatic etiology. Functional dyspepsia (non-ulcer dyspepsia) defined as recurrent or chronic upper abdominal discomfort or pain for a at least three months with symptoms exists $>25$ percent of the time, along with absence of biochemical, clinical, ultrasonographic and endoscopic evidence of any organic disorder responsible for symptoms. ${ }^{6}$ The most common clinical issue in gastroenterology is Helicobacter pylori $(\mathrm{Hp})$ infection and functional dyspepsia
(FD) but their association remains unclear and disputed. ${ }^{8}$ The prevalence of $\mathrm{H}$. pylori in functional dyspepsia reported as $87 \%,{ }^{9}$ but remains unclear either an associated finings or $\mathrm{H}$. pylori infection is responsible for the symptoms. Former trials determined the non ulcer dyspepsia managed by eradication of $\mathrm{H}$. pylori with conflicting results but some studies reported subsiding of symptoms with eradication treatment in individuals with nonulcer dyspepsia. ${ }^{9-12}$ Thus, this study planned to conducted at tertiary care hospital to evaluate the frequency of $\mathrm{H}$. pylori in individuals with functional dyspeptic symptoms so that early effective measure can be taken to save the individuals from life threatening complications associated with $\mathrm{H}$. pylori.

\section{PATIENTS AND METHODS}

The six months (01-May-2014 to 31-10-2014) cross sectional descriptive study was conducted at Department of Gastroenterology, Liaquat National Hospital Karachi. The Sample Size was 
calculated by considered the prevalence of Helicobacter pylori in functional dyspepsia $87 \%{ }^{9}$ with $06 \%$ margin of error. Total 121 functional dyspeptic patients were taken.

The inclusion criteria were the patients of $18-70$ years, either gender presented with functional dyspepsia for more than 03 months duration.

The exclusion criteria were patients already on Helicobacter pylori eradication therapy, gastroesophageal reflux disease or irritable bowel syndrome and previous gastrointestinal surgery.

\section{(A) Functional Dyspepsia}

The functional dyspepsia was detected according to the Rome III Diagnostic Criteria for Functional Gastrointestinal Disorders. ${ }^{13}$

*The criteria fulfilled for the symptom onset at least for 03 months prior to diagnosis.

\section{(B) Helicobacter Pylori Infection}

Detected on mucosal biopsy specimen taken during endoscopy and sent to laboratory for histopathology and considered as positive when Helicobacter pylori infection is detected. The gram stain demonstrated the spiral bacillus of Helicobacter pylori, the organism can be seen within the mucus extruding from the foveolar pits showed a proliferating colony of Helicobacter pylori obtained by biopsy.

The data was collected from patients with functional dyspepsia attended Gastroenterology out and in patient department. All patients were evaluated for $\mathrm{H}$. pylori infection. The informed consent was taken and all patients were underwent Gastroscopy and histopathological evaluation was reported by histopathologist while all the relevant information was entered on the annexed proforma.

Statistical package of social sciences (SPSS version 13) was used for analysis and chi-square test was applied and the p-value $\leq 0.05$ was considered as statistically significant.

\section{RESULTS}

Total 121 patients with functional dyspepsia were evaluated for Helicobacter pylori infection. The mean age $\pm S D$ of functional dyspeptic patients was $41.74 \pm 08.87$ while of Helicobacter pylori infected individuals were $40.70 \pm 7.82$ whereas it was $40.55 \pm 10.63$ in $\mathrm{H}$. pylori negative subjects. The results are presented in Table-I-IV.

\begin{tabular}{|c|c|c|c|c|c|}
\hline & & \multicolumn{2}{|c|}{ Gender } & \multirow[t]{2}{*}{ Total } & \multirow[t]{2}{*}{ P-Value } \\
\hline & & Male & Female & & \\
\hline \multirow[t]{10}{*}{ Age } & $18-29$ & 5 & 4 & 9 & \multirow{12}{*}{$0.02^{*}$} \\
\hline & & $6.7 \%$ & $8.7 \%$ & $7.4 \%$ & \\
\hline & $30-39$ & 31 & 24 & 55 & \\
\hline & & $41.3 \%$ & $52.2 \%$ & $45.5 \%$ & \\
\hline & $40-49$ & 34 & 9 & 43 & \\
\hline & & $45.3 \%$ & $19.6 \%$ & $35.5 \%$ & \\
\hline & $50-59$ & 3 & 7 & 10 & \\
\hline & & $4.0 \%$ & $15.2 \%$ & $8.3 \%$ & \\
\hline & $60-70$ & 2 & 2 & 4 & \\
\hline & & $2.7 \%$ & $4.3 \%$ & $3.3 \%$ & \\
\hline \multirow[t]{2}{*}{ Total } & & 75 & 46 & 121 & \\
\hline & & $100.0 \%$ & $100.0 \%$ & $100.0 \%$ & \\
\hline
\end{tabular}

Table-l. The age according to gender

\begin{tabular}{|c|c|c|c|c|c|}
\hline & & \multicolumn{2}{|c|}{ H. Pylori } & \multirow[t]{2}{*}{ Total } & P-Value \\
\hline & & Positive & Negative & & \multirow{13}{*}{$0.03^{*}$} \\
\hline \multirow[t]{10}{*}{ Age } & $18-29$ & 3 & 6 & 9 & \\
\hline & & $3.8 \%$ & $14.0 \%$ & $7.4 \%$ & \\
\hline & $30-39$ & 34 & 21 & 55 & \\
\hline & & $43.6 \%$ & $48.8 \%$ & $45.5 \%$ & \\
\hline & $40-49$ & 33 & 10 & 43 & \\
\hline & & $42.3 \%$ & $23.3 \%$ & $35.5 \%$ & \\
\hline & $50-59$ & 7 & 3 & 10 & \\
\hline & & $9.0 \%$ & $7.0 \%$ & $8.3 \%$ & \\
\hline & $60-70$ & 1 & 3 & 4 & \\
\hline & & $1.3 \%$ & $7.0 \%$ & $3.3 \%$ & \\
\hline \multirow[t]{2}{*}{ Total } & & 78 & 43 & 121 & \\
\hline & & $100.0 \%$ & $100.0 \%$ & $100.0 \%$ & \\
\hline
\end{tabular}

Table-II. The age accordance to helicobacter pylori infection

\begin{tabular}{|c|c|c|c|c|c|}
\hline & & \multicolumn{2}{|c|}{ Gender } & \multirow[t]{2}{*}{ Total } & \multirow[t]{2}{*}{ P-Value } \\
\hline & & Male & Female & & \\
\hline \multirow[t]{4}{*}{ H. Pylori } & Positive & 55 & 23 & 78 & \multirow{6}{*}{$<0.01^{*}$} \\
\hline & & $73.3 \%$ & $50.0 \%$ & $64.5 \%$ & \\
\hline & Negative & 20 & 23 & 43 & \\
\hline & & $26.7 \%$ & $50.0 \%$ & $35.5 \%$ & \\
\hline \multirow[t]{2}{*}{ Total } & & 75 & 46 & 121 & \\
\hline & & $100.0 \%$ & $100.0 \%$ & $100.0 \%$ & \\
\hline
\end{tabular}

Table-III. The gender according to helicobacter pylori infection 


\begin{tabular}{|c|c|c|c|c|c|}
\hline & & \multicolumn{2}{|c|}{ H.Pylori } & \multirow[t]{2}{*}{ Total } & P-Value \\
\hline & & Positive & Negative & & \multirow{11}{*}{$0.35^{*}$} \\
\hline \multirow[t]{8}{*}{$\begin{array}{l}\text { Duration } \\
\text { (Months) }\end{array}$} & $3-6$ & 17 & 4 & 21 & \\
\hline & & $21.8 \%$ & $9.3 \%$ & $17.4 \%$ & \\
\hline & $6-9$ & 33 & 21 & 54 & \\
\hline & & $42.3 \%$ & $48.8 \%$ & $44.6 \%$ & \\
\hline & $9-12$ & 19 & 11 & 30 & \\
\hline & & $24.4 \%$ & $25.6 \%$ & $24.8 \%$ & \\
\hline & $>12$ & 9 & 7 & 16 & \\
\hline & & $11.5 \%$ & $16.3 \%$ & $13.2 \%$ & \\
\hline \multirow[t]{2}{*}{ Total } & & 78 & 43 & 121 & \\
\hline & & $100.0 \%$ & $100.0 \%$ & $100.0 \%$ & \\
\hline
\end{tabular}

\section{DISCUSSION}

The functional dyspepsia etiology remains unclear although the relationship with $\mathrm{H}$. pylori has been detected formerly. In present study, $64.4 \%$ patients had positive and $35.5 \%$ had negative $\mathrm{H}$. pylori infection and is consistent with former literature as $62 \%, 58 \%$ and $68 \%$ for $\mathrm{H}$. pylori infection associated with functional dyspepsia. ${ }^{14-16}$ The pathogenesis include altered gastric emptying alterations and accommodation of stomach and gastroduodenal hypersensitivity. ${ }^{17-19}$ Some studies observed delays gastric emptying by $\mathrm{H}$. pylori which improves by eradication therapy although former literature failed to confirm it. ${ }^{20}$ $\mathrm{H}$. pylori infection leads to dyspepsia by gastric acid secretion, gastric mucosa inflammation and pathological changes. It has been observed that found that non-ulcer dyspepsia \& infected subjects stimulates maximal acid output as compared to uninfected controls..$^{21,22} \mathrm{H}$. pylori alters release of gastrin \& somatostatin as well as of ghrelin and these alterations normalize following eradication therapy. ${ }^{23,24}$ Certain genetic factors play a role $\mathrm{H}$. pylori-associated gastritis. ${ }^{25}$ Indeed, despite of existence of infection majority of individuals with $\mathrm{H}$. pylori infection are asymptomatic and leads to chronic gastritis. The polymorphonuclear infiltration completely subsides following eradication while the lymphocytic infiltrate in gastric mucosa persist and exists for several months to years and these cell are responsible for releasing cytokines responsible for inflammatory process. $^{26-28}$ Talley NJ observed that $50 \%$ individuals with functional dyspepsia spare from etiology and labeled as functional or idiopathic. ${ }^{12}$

In present series $72 \%$ dyspeptic patients were from low socioeconomic status and is reported as $80 \%$ in the study by Graftie J, et al..$^{29}$ In present study the male population were in majority and is consistent with the study of Rocar et al while the study by Heikkinen $\mathrm{M}$, et al is contrast. ${ }^{30,31}$

Pash Le R, et al observed $80 \%-90 \%$ dyspeptic subjects have associate epigastric pain, bothersome postprandial fullness, early satiety, anorexia and regurgitation. ${ }^{32}$ In present study majority of patients (54) had symptoms for six to nine months and 30 patients had for 9-12 months, the findings are consistent with the study by Perri $\mathrm{F}$, et al ${ }^{33}$ Further advance and multidisciplinary studies should be planned and conduct to evaluate the etiology of symptoms and response of eradication therapy.

\section{CONCLUSION}

$\mathrm{H}$. pylori responsible for causing functional dyspeptic symptoms \& in present study the proportion for $\mathrm{H}$. pylori was reported as $64.4 \%$ with male predominance (71\%) between $30-39$ years age group.

Copyright $\odot 19$ Sep, 2018.

\section{REFERENCES}

1. Ahmed J, Haider SI, Choudhri AN. Dyspepsia in a rural cohort. J Coll Physicians Surg Pak. 2004; 14(2):91-3.

2. Devrajani BR, Shah SZ, Soomro AA, Devrajani T. Type 2 diabetes mellitus: A risk factor for Helicobacter pylori infection: A hospital based case-control study. Int J Diabetes Dev Ctries. 2010; 30(1):22-6.

3. Taddesse G, Habteselassie A, Desta K, Esayas S, Bane A. Association of dyspepsia symptoms and Helicobacter pylori infections in private higher clinic, Addis Ababa, Ethiopia. Ethiop Med J. 2011; 49(2):10916.

4. Vakil N. Dyspepsia, peptic ulcer, and H. pylori: A remembrance of things past. Am J Gastroenterol. 2010; 105(3):572-4.

5. Mc Namara DA, Buckley M, O'Morain CA. Nonulcer dyspepsia. Current concepts and management. Gastroenterol Clin North Am. 2000; 29:807-18. 
6. Talley NJ, Colin-Jones D, Koch KL, Koch M, Nyren O, Stanghellini V. Functional dyspepsia: A classification with guidelines for diagnosis and management. Gastroenterol Int.1991; 4:145-60.

7. Mc Namara DA. Buckley M, O'Morain CA. Nonulcer dyspepsia. Current concepts and management. Gastroenterol Clin North Am. 2000; 29:807-18.

8. Armstrong D. Helicobacter pylori infection dyspepsia. Scand J Gastroenterol Suppl.1996; 215:38-47.

9. Shrivastava UK, Gupta A, Gupta A, Bhatia A. Role of helicobacter pylori in functional dyspepsia. Indian $\mathrm{J}$ Surg. 2004; 66:341-6.

10. O'Morain C. Role of Helicobacter pylori in functional dyspepsia. World J Gastroenterol. 2006; 12(17):267780.

11. Mazzoleni LE, Sander GB, Francesconi CF, Mazzoleni F, Uchoa DM, De Bona LR, et al. Helicobacter pylori eradication in functional dyspepsia: HEROES trial. Arch Intern Med. 2011; 171(21):1929-36.

12. Talley N, Mccoll K. H pylori and functional dyspepsia. Gut. 2001; 49(5): 738-9.

13. Mearin F, Calleja JL. Defining functional dyspepsia. Rev Esp Enferm Dig. 2011; 103(12):640-7.

14. Ansari S, Shahwani IM, Channa AA, Shah SZA, Devrajani T. Helicobacter pylori; Patients with functional dyspepsia. Professional Med J. 2014; 21 (4):679-83.

15. Sodhi JS, Javid G, Zargar SA, Tufail S, Shah A, Khan BA, et al. Prevalence of Helicobacter pylori infection and the effect of its eradication on symptoms of functional dyspepsia in Kashmir, India. J Gastroenterol Hepatol. 2013; 28(5):808-13.

16. Nafeeza MI, Isa MR, Kudva MV, Ishak MS, Mazlam MZ, Haron A, et al. Helicobacter pylori related functional dyspepsia in a defined Malaysian population. Malays J Med Sci. 2000; 7(1):22-6.

17. Tack J, Talley NJ, Camilleri M, Holtmann G, $\mathrm{Hu}$ P, Malagelada JR, Stanghellini V. Functional gastroduodenal disorders. Gastroenterology 2006; 130:1466-79.

18. Tack J, Piessevaux H, Coulie B, Caenepeel P, Janssens $\mathrm{J}$. Role of impaired gastric accommodation to a meal in functional dyspepsia. Gastroenterology 1998; 115 : 1346-52.

19. Sarnelli G, Cuomo R, Janssens J, Tack J. Symptom patterns and pathophysiological mechanisms in dyspeptic patients with and without Helicobacter pylori. Dig Dis Sci 2003; 48:2229-36.
20. Talley NJ, Xia HH. Helicobacter pylori infection and nonulcer dyspepsia. Br Med Bull 1998; 54:63-9.

21. el-Omar EM, Penman ID, Ardill JE, Chittajallu RS, Howie C, McColl KE. Helicobacter pylori infection and abnormalities of acid secretion in patients with duodenal ulcer disease. Gastroenterology.1995; 109:681-91.

22. el-Omar E, Penman I, Ardill JE, McColl KE. A substantial proportion of non ulcer dyspepsia patients have the same abnormality of acid secretion as duodenal ulcer patients. Gut.1995; 36: 534-538.

23. Suzuki $H$, Moayyedi P. Helicobacter pylori infection in functional dyspepsia. Nat Rev Gastroenterol Hepatol. 2013; 10:168-74.

24. McColl K, Murray L, El-Omar E, Dickson A, El-Nujumi A, Wirz A,et al. Symptomatic benefit from eradicating Helicobacter pylori infection in patients with nonulcer dyspepsia. N Engl J Med. 1998; 339:1869-74.

25. Tahara T, Shibata T, Yamashita H, Hirata I, Arisawa T. The Role of RANTES Promoter Polymorphism in Functional Dyspepsia. J Clin Biochem Nutr. 2009; 45:235-40.

26. Dixon MF, Genta RM, Yardley JH, Correa P. Classification and grading of gastritis. The updated Sydney System. International Workshop on the Histopathology of Gastritis, Houston 1994. Am J Surg Pathol.1996; 20:1161-81.

27. Fock KM. Functional dyspepsia, H. pylori and post infectious FD. J Gastroenterol Hepatol. 2011; 3:39-41

28. Li XB, Chen HM, Lu H, Zheng Q, Chen XY, Peng YS, et al. Role of Helicobacter pylori infection on neuronal expression in the stomach and spinal cord of a murine model. J Dig Dis. 2009; 10:286-92.

29. Graftie J, Dixon MF. Therapy for H. Pylori in NUD a meta-analysis of randomized controlled trials. Gastroenterol. 2000; 160:186.

30. Rocar, Pursey. The role of $\mathbf{H}$. Pylori in NUD. Gastroenterology. 1998; 114:633-39.

31. Heikkinen M, Pikkarainen P, Takala J. Etiology of dyspepsia: Four hundred unselected consecutive patients in general practice. Scand $J$ Gastroenterol.1995; 30:519.

32. Pash Le R, Jishop HY. H.pylori infection and abnormalities of acid secretion in patient with chronic duodenal ulcer disease. Gastroenterology.1995; 109:681-87. 
33. Perri F, Clemente R, Festa V, Annese V, Quitadamo M, Rutgeerts $P$, et al. Patterns of symptoms in functional dyspepsia: role of Helicobacter pylori infection and delayed gastric emptying. Am J Gastroenterol.1998; 93(11):2082-8.

\section{AUTHORSHIP AND CONTRIBUTION DECLARATION}

\begin{tabular}{|c|c|c|c|}
\hline Sr. \# & Author-s Full Name & Contribution to the paper & Author $=$ s Signature \\
\hline 1 & Tooba & $\begin{array}{l}\text { Contributions to conception } \\
\text { and design, acquisition of data, } \\
\text { analysis and interpretation of } \\
\text { data. }\end{array}$ & \\
\hline 2 & Riaz Hussain Awan & $\begin{array}{l}\text { Drafting the article and shares } \\
\text { its expert research opinion } \\
\text { and experience in finalizing the } \\
\text { manuscript. }\end{array}$ & \\
\hline 3 & Seema Nayab & $\begin{array}{l}\text { Contributed in conception and } \\
\text { interpretation of data and give } \\
\text { his expert view for manuscript } \\
\text { designing. } \\
\text { Data analysis and interpretation. }\end{array}$ & \\
\hline 5 & Faqir Muhammad Awan & $\begin{array}{l}\text { Collection and acquisition } \\
\text { of data, analysis and } \\
\text { interpretation of data and make } \\
\text { it suitable for final version and a } \\
\text { corresponding author. }\end{array}$ & \\
\hline
\end{tabular}

